\title{
Vražje oko
}

\author{
Radoslav Katičić
}

East of Križevci in the northwest of Croatia there is a plateau with a stream called Vražje Oko (Devil's Eye), whose name illustrates how before the Christian Era the local Slavic population sacralized its immediate environment. Named after its source, the stream may be interpreted as the Eye of god Veles, who is closely connected with water, and is the opponent of the thunder god. The name, as well as its perception, indicates that its origin may be traced to Balto-Slavic pagan beliefs.

Keywords: eye, spring, Veles, devil

Toponim Vražje oko, potvrđen na Tremi, visoravni istočno kraj Križevaca, onkraj rijeke Glogovnice, opisan je kao ime vode (hidronim) ${ }^{1}$ i kao ime naselja (ojkonim) ${ }^{2}$. Po sasvim prozirnoj etimologiji jasno se razabire da je to ime prvotno nadjenuto vodi, a onda je po vodi na kojoj leži dobilo ime i naselje. To je sasvim uobičajena postupnost pri nadijevanju mjesnih imena. No Vražje oko po svojoj je etimologiji zapravo ime vrela, pa je potok nazvan po svojem vrelu.

To nam jasno kaže Karadžić nabrajajući značenja riječi oko u svojem »Srpskom rječniku«. Među ostalim tu su: 3) »izvor gdje voda tiho teče« i 4) »u jezeru Skadarskome kraj brijega Crnogorskoga onako mjesto gdje se voda čini drukčija nego u ostalome jezeru. Po svoj prilici na ovijem mjestima u dubini izvire voda«. U slovenskom jeziku okô znači i »duboko mjesto u rijeci gdje odozdol udara vrelo« i »dio rijeke ograđen za ribolov«. Slovački pak morské oko znači »duboko jezero u visokom gorju«. ${ }^{3}$ To su jezera kojima se ne vidi pritoka, pa se doživljavaju kao da su sama svoja vrela. A u Hrvatskoj je potvrđen hidronim Zmajevo oko i to četiri puta./Tako se zovu mala jezera kraj Imotskoga i kod Rogoznice blizu Šibenika. Zmajevo oko nadalje se zove podmorska špilja na Braču i rupa vidljiva na površini na Dugom otoku. ${ }^{4}$ Odatle se vidi da je vrag/kojega je to oko/upravo zmaj. A zmaj je Veles. Vražje oko tako zapravo znači »vražje vrelo«, ali je ono i »zmajevo vrelo«, a to će reći da je »Velesovo vrelo«.

\footnotetext{
1 Usp. Goss, Vladimir P., Two St. Georges and the Earliest Slavic Cultural Landscape Between the Sava and the Drava Rivers, Peristil 51, Zagreb 2008,18-20 i slika 18 na str. 16.

2 Usp. Veliki atlas Hrvatske, Zagreb 2002, 23 B-1.

3 Usp. Толстой, Никита Ильич, Славянская географическая терминология, Семасиологические этюды, Москва 1969, 208.

4 Za te podatke zahvaljujem Damiru Zoriću, Tiboru Komaru, Mislavu Ježiću i Vitomiru Belaju. Zahvaljujem i Tomi Vinšćaku na usrdnom posredovanju podataka.
} 
Taj hidronim nedvojbeno je baština baltoslavenske starine. O tome svjedoči takva poraba riječi koja praslavenski glasi oko, a u baltičkom litavski akis i latvijski acs, oboje »oko«. Ta je riječ indoeuropska i podudarna s grčkim ő $\mu \alpha$ i ỏ $\varphi \theta \alpha \lambda \mu o ́$, latinski oculus, sve troje »oko«. Ta riječ i u baltičkom ima značenja koja Karadžić navodi za »srpsko« oko. Ivanov i Toporov ${ }^{5}$, svjesni vjerskoga značenja te riječi u baltoslavenskom, donose za to ove potvrde: litavski akis znači i »mjesto u močvari koje nije obraslo mahovinom « te vandeñs akis »vrelo«, doslovno »oko vode«, tj. »vodeno oko«.

Bliskosrodna praslavenska riječ okzno > okno u hrvatskome i srpskom kao òkno po svjedočanstvu Akademijina rječnika znači i »čisto, nezaraslo mjesto u blatu «, »nezamrzlo mjesto na blatu«. To je značenje praslavensko. U slovenskome ókno znači »duboko mjesto u vodi, blatu «. U starome poljskom okno pak znači »vrelo«, a u današnjem jeziku i »jezerсе«, »nezaraslo mjesto u blatu«. Bjeloruski, ruski i ukrajinski ta riječ, акно́, окно́, вікно́, znači »čista voda u močvari«, »duboka jama u močvari«. ${ }^{6}$ Sve to dodatno potvrđuje i ukrjepljuje praslavensko značenje riječi oko koje se odnosi na hidrografske danosti.

Veza pak s bogom Velesom, gromovnikovim protivnikom izričito se potvrđuje latvijskim izrazom velna acs, koji ne znači drugo nego »vražje oko«, a njime se označuje neobrasla vodena površina u močvari. Latvijsko velna acs, ako se razumije doslovno, znači dakle isto kao ime vrela, potoka i zaseoka Vražje oko na Tremi. Razlika je tek u tome što je u latvijskom natprirodno biće, gromovnikov protivnik, i u ulozi kršćanskoga vraga zadržalo svoje prvotno ime izvedeno od korijena vel-, a na Tremi nije. U Latvijaca je kršćanski vrag, što je od praslavenskoga vorgz »neprijatelj«, nazvan velns, a u hrvatskom i drugom slavenskome nije nazvan imenom koje bi odavalo vezu s tim korijenom i imenom poganskoga boga Velesz.

Vražje oko je dakle zapravo Velesovo oko, vrelo pri duplji u korijenju drveta svijeta. Tamo na Tremi tako je interpretiran krajolik u kojem i drugi toponimi i stara svetišta, pretvorena u kršćanske crkve, najvjerojatnije svjedoče o slavenskom poganskom kulturnom sloju. Takvu interpretaciju tih imena i pripadnih zemljišnih konfiguracija jako podupire taj nedvbojbeni trag baltoslavenske pretkršćanske vjerske tradicije.

Uostalom, toponim Vražje oko, potvrđen na visoravni Trema kod Križevaca, već je doveden u vezu s Velesom, bogom podzemlja, đavolom i zmijom. ${ }^{7}$ Povezan je s njim bez potvrda i argumenata, kao da je samo po izoštrenoj i načitanoj intuiciji. Ali povezan je ispravno!

Iz svega se toga nedvojbeno razabire koliko je važno i vrijedno otkriće toponima Vražje oko. Ono ozbiljno obogaćuje naše znanje o pretkršćanskom slavenskom kulturnom sloju na hrvatskom ozemlju.

\footnotetext{
5 Usp. Иванов, Вячеслав Всеволодович - Владимир Николаевич Топоров, Исследовгания в области славянских древностей. Лексические и фразеологические вопросы реконструкции текстов, Москва 1974, 129-130.

6 Usp. Толстой, nav, dj,, 207-210.

7 Usp. Goss, nav. dj., 20.
} 


\section{Der Gewässername »Vražje oko»}

\section{Radoslav Katičić}

Der Name eines Baches Vražje oko »Teufelsauge«, belegt auf einer Hochebene, die östlich gleich neben der Stadt Križevci gelegen ist, bewahrt eine Spur slawischer vorchristlicher sakraler Interpretation des Geländes. Der Bach ist nach seiner Quelle benannt, diese wird aber als Auge des Gottes Veles, des Gegners des Donnergottes, der mit Wasser engstens verbunden ist, aufgefasst. Eine solche Auffassung und Benennung von Quellen ist eindeutig als Tradition baltoslawischen Heidentums zu belegen. Davon zeugt auch dieser Gewässeername im Nordwesten Kroatiens. 